IZA DP No. 6144

Welfare Participation by Immigrants in the UK

Stephen Drinkwater

Catherine Robinson

November 2011

Forschungsinstitut zur Zukunft der Arbeit Institute for the Study of Labor 


\title{
Welfare Participation by Immigrants in the UK
}

\author{
Stephen Drinkwater \\ Swansea University, \\ CREAM, University College London and IZA \\ Catherine Robinson \\ Swansea University \\ and NIESR
}

Discussion Paper No. 6144

November 2011

\author{
IZA \\ P.O. Box 7240 \\ 53072 Bonn \\ Germany \\ Phone: +49-228-3894-0 \\ Fax: +49-228-3894-180 \\ E-mail: iza@iza.org
}

\begin{abstract}
Any opinions expressed here are those of the author(s) and not those of IZA. Research published in this series may include views on policy, but the institute itself takes no institutional policy positions.

The Institute for the Study of Labor (IZA) in Bonn is a local and virtual international research center and a place of communication between science, politics and business. IZA is an independent nonprofit organization supported by Deutsche Post Foundation. The center is associated with the University of Bonn and offers a stimulating research environment through its international network, workshops and conferences, data service, project support, research visits and doctoral program. IZA engages in (i) original and internationally competitive research in all fields of labor economics, (ii) development of policy concepts, and (iii) dissemination of research results and concepts to the interested public.
\end{abstract}

IZA Discussion Papers often represent preliminary work and are circulated to encourage discussion. Citation of such a paper should account for its provisional character. A revised version may be available directly from the author. 
IZA Discussion Paper No. 6144

November 2011

\section{ABSTRACT}

\section{Welfare Participation by Immigrants in the UK}

Welfare participation is an important indicator of how successfully immigrants perform in the host country. This paper examines this issue for the UK, which has experienced a large growth in its immigrant flows and population levels in recent years, especially following EU enlargement in 2004. The analysis focuses in particular on the types of benefits that immigrants tend to claim as well as examining differences by area of origin. It also examines the factors that determine social benefit claims, including an investigation of the impact of education, ethnicity and years since migration. Social welfare claims vary considerably by immigrant group as well as by the type of benefit claimed in the UK. There is also some variation by gender within the migrant groups.

JEL Classification: J61, F22, I38

Keywords: $\quad$ immigration, United Kingdom, benefit claims, EU enlargement

Corresponding author:

Stephen Drinkwater

Wales Institute of Social and Economic Research, Data and Methods

School of Business and Economics

Swansea University

Swansea, SA2 8PP

United Kingdom

E-mail: s.j.drinkwater@swansea.ac.uk

\footnotetext{
* Material from the Quarterly Labour Force Survey is Crown Copyright and has been made available by the Office for National Statistics through the Data Archive at the University of Essex. The views expressed in this work and errors therein are those of the author.
} 


\section{Introduction}

A negative view that is often directed towards immigrants is that they are more heavily dependent on welfare payments than natives. Evidence on this issue is not entirely clear cut, with mixed results produced by studies from a range of countries. Many of these have found that immigrants are more likely to receive welfare payments including Borjas and Hilton (1996) for the US, Lofstram and Hansen (2003) for Sweden and Blume and Verner (2007) for Denmark. In contrast, studies such as Baker and Benjamin (1995) for Canada and Gustmann and Steinmeier (2000) for US males have found the reverse. Conflicting results have also been obtained on the issue of whether immigrants assimilate into or out of welfare dependence. ${ }^{1}$ The current paper uses data from the UK to compare immigrants and natives in terms of their participation within the welfare system in general, as well as examining the specific type of benefits that they receive. The UK provides a good case study with which to undertake such an analysis since it has experienced a large increase in immigration in recent years. For example, estimates produced by Oxford Economics (2009) indicate that the immigrant population in the UK more than doubled, from 3.2 million to 6.6 million, between 1991 and 2008. The majority of the increase has occurred since 2001 and the main factor behind this expansion was the migration flows emanating from Eastern Europe following EU enlargement in 2004. Therefore, given the UK's recent history and the diversity of its immigrants it is also interesting to observe how welfare participation varies between migrants from different regions of origin.

Despite the recent increase in migration to the UK, there does not currently exist much evidence on welfare participation by immigrants in the UK. One exception is Barrett and McCarthy (2008) who, after reviewing evidence on welfare receipt by

\footnotetext{
${ }^{1}$ See Pekkala Kerr and Kerr (2009) for a discussion of such studies.
} 
immigrants in other countries, use the British Household Panel Survey (BHPS) to examine differences in the receipt of benefits between immigrants and natives. Their main conclusion is that immigrants are less likely to receive welfare payments but given the nature of the BHPS sample they only have a relatively small number of immigrants, which includes a relatively high proportion from Ireland. There are also a few other studies that attempt to estimate the fiscal impact of immigration to the UK. These include Gott and Johnston (2002) and Dustmann et al. (2009). Both of these studies use the Labour Force Survey (LFS) to examine differences in welfare claims between immigrants and natives since the LFS provides the most extensive continuous source of information on the socio-economic circumstances of migrants in the UK. This is also the main data source to be examined in this paper but it is used in a slightly different manner to the previously mentioned studies as the focus here is on the incidence of welfare claims by immigrants and what determines these rather than on attempting to estimate the net fiscal contribution of immigrants.

The present paper is structured as follows. The next section describes recent changes in immigration to the UK, focusing particularly on the period since EU enlargement in 2004. This is followed by a discussion of the main welfare schemes that are currently in place in the UK. Section 4 contains some background statistics on welfare participation by immigrants and also describes the data used in the econometric analysis, which appears in Section 5. The final section contains some concluding comments. 


\section{Recent Trends in Immigration to the UK}

The recent rise in immigration to the UK has been fairly well documented, particularly in relation to the flows that followed the accession of the new EU member states from Central and Eastern Europe, who joined the EU in May 2004 (henceforth known as the EUA8. ${ }^{2}$ In addition, the UK has received, and continues to receive, large flows of immigrants from parts of its former empire, especially from India, Pakistan and Bangladesh, as well as previously from the Caribbean. Table 1 presents the picture resulting from such movements from a viewpoint of immediately prior to EU enlargement by reporting the distribution of immigrants in the first quarter of 2004 by area of origin and time of arrival in the UK. The areas of origin are largely based on continents but Europe has been split into three parts: the EUA8; the other member states of the EU prior to 2004 (henceforth known as the EU14) and Other Countries. These data have been obtained from the LFS and use 2007 population weights to gross up the estimates. The estimated UK immigrant population reported in the table is over 100,000 higher than the figure recorded in the 2001 Census due to positive net migration in the intervening years.

Table 1 indicates that almost a third of immigrants in the UK at this time had been born in Asia, mainly in its former colonies, especially India, Pakistan and Bangladesh. Immigration from these countries has remained high since large numbers of migrants began arriving in the UK from the Indian sub-continent in the 1960s. Other substantial immigrant flows have come from Africa, the EU14 and the Americas. For the latter group, it can be seen that a fairly high proportion of immigrants settled during the 1960s, a period when migration from the West Indies was strong. In contrast, there were relatively few immigrants from either EUA8

\footnotetext{
${ }^{2}$ See for example Blanchflower and Lawson (2009); Clark and Drinkwater (2008) and Lemos and Portes (2008), each of which also discuss some labour market implications of these migration flows.
} 
countries or other parts of Europe living in the UK in early 2004. Only a small percentage of EUA8 migrants resident in the UK at this time arrived between 1950 and 1980, whereas the majority had entered in the years preceding enlargement. A noticeable amount also arrived before 1950, which mainly relates to the influx of Polish refugees and ex-servicemen in the immediate aftermath of the Second World War (Drinkwater et al., 2009).

The extent of the recent migration flows from Eastern Europe can be seen from Figure 1. These data are taken from the National Insurance Numbers (NINos) issued to overseas nationals, which have been collected by the Department of Work and Pensions. This is generally recognised as the most reliable source of information on recent migrant flows to the UK. The reason for this is that all new entrants wishing to work in the UK or to claim benefits require a NI number. In contrast to the Workers Registration Scheme (WRS), which has also been used to document the rise in migration from the EUA8 to the UK (Blanchflower and Lawton, 2009; Lemos and Portes, 2008), the NINo data represents a more complete record of entrants as it covers the self-employed plus a fairly high proportion of EUA8 migrant workers have not actually registered on the WRS (Clark and Drinkwater, 2008). However, the NINo data do have some problems of its own including that overseas nationals can apply for a NI number in their home countries even if they do not actually move to the UK and it does not provide information on how long those entering the UK stay for.

Table 2 shows that total NINo registrations more than doubled between 2002/3 and 2006/7, reaching their peak in 2007/8 when more than 733,000 overseas nationals registered for a NINo. Registrations fell back in 2008/9, with the slowdown in the UK labour market, and this was largely the result of a decline in registrations from EU accession countries, as can be seen from Figure 1. In the previous year there 
were more than 330,000 registrations from accession countries (which includes Bulgaria and Romania), accounting for more than $45 \%$ of total applications, more than 11 times the amount seen in the year prior to EU enlargement. ${ }^{3}$ The initial growth in migration from accession countries can be attributed to the UK being only one of three EU member states to allow labour to move more or less freely from the EUA8 but flows continued to rise until the recession started despite the relaxation of restrictions in other member states. Figure 1 reveals that registrations have been on an upward trend from the remainder of the EU, whilst there have been only small flows from other parts of Europe. Registrations from Asia and the Middle East have also risen quite considerably since 2004/5.

Table 2 also contains some of the main characteristics of recent migrants to the UK using NINo data for 2002/3-2008/9. It shows that migrants are mainly young, with around $80 \%$ aged between 18 and 34 in each year. However, the proportion aged 18-24 has increased in more recent years, as a result of the younger age profile of EUA8 migrants. Flows from the EUA8 have also been more male dominated and thus a higher percentage of migrants have been male since enlargement. Migration to the UK has also become more geographically dispersed since 2004, with recent migrants far less likely to settle in London and the South East. In particular, large numbers of EUA8 migrants have moved to less populated and more remote areas (Clark and Drinkwater, 2008). Table 2 provides further information on the area of origin of recent migrants by reporting the nationality of registrants. It highlights the large influx of workers from Poland, with Poles accounting for almost a third of all migrants to the UK in 2006/7. Migration from the rest of the EUA8 peaked during the previous year,

\footnotetext{
${ }^{3}$ Following the large migrant flows from the EUA8 after enlargement, restrictions were imposed on the migration of Bulgarians and Romanians to the UK. Migrants from these countries can only generally work in the UK if they are self-employed or employed through particular schemes rather than being subject to the same access to the labour market as enjoyed by EUA8 migrants. See Clark and Drinkwater (2008) for a more detailed discussion.
} 
when registrations from these countries reached around 15\% of the total. Despite the large fall in migration from the EUA8 in 2008/9, these countries still accounted for almost a third of registrations in this year, with around 20\% from Poland. After Poland, the next highest number of migrants have arrived from India in recent years but registrations from this country has accounted for less than $10 \%$ of the annual total.

Before moving onto discuss the UK welfare systems and the relative use of this by immigrants, Tables 3 and 4 contain useful background information on recent employment trends for individuals from different countries of origin. These data have been published by the Office for National Statistics (ONS) and are again based on LFS estimates. These tables also provide the role of illustrating firstly the growth of the UK labour market in the early part of the last decade and then its decline towards its end. Table 3 reveals that employment levels for the UK born began to decline in 2006 but this did not occur for those born outside of the UK until 2009. It again shows the rapid growth in workers from the EUA8, with employment levels increasing from 47,000 in 2003 to 515,000 in 2008. Similarly, employment levels from most areas of origin also peaked in 2008, except from the residual 'Other' areas, which has seen its employment numbers continue to have been boosted by migrants from Bulgaria and Romania, following EU enlargement in 2007. Table 4 shows that employment rates fell by two percentage points for both the UK and immigrants between the third quarters of 2008 and 2009. Although overall employment rates have been lower for the non-UK born, they rose by around 3 percentage points between 2004 and 2008. Again migration flows from the EUA8 can explain this change since well over $80 \%$ of migrants from these countries have been in employment since 2005. Employment rates are highest of all from migrants from Australia and New Zealand and were of a similar order for South African migrants for 2006-8. Employment rates are by far the 
lowest for immigrants from Pakistan and Bangladesh, with less than $50 \%$ in employment in each year. This can be explained by the low rates of economic activity displayed by females from these countries, much of which is due to cultural factors (Clark and Drinkwater, 2009).

\section{The UK Benefits and Tax Credits System}

In common with many other advanced economies, the benefits system in the UK is quite complex and has changed substantially over recent decades. ${ }^{4}$ Cappellari and Jenkins (2009) distinguish between two main types of social benefits. The first are social assistance benefits, which are income-tested cash benefits and are also often referred to as welfare benefits. In relation to the UK, Cappellari and Jenkins (2009) identify four main categories of social assistance benefits for people of working age. These are Income Support (IS), income-based Job Seekers Allowance (JSA), Housing Benefit and Council Tax Benefit. Individuals receive JSA if they are out of work and looking for employment providing they have made sufficient National Insurance contributions. JSA can either be contribution- or income-based. IS is provided to those on low incomes who are not eligible for JSA, including lone parents, sick people and pensioners. Council Tax Benefit and Housing Benefit can be received by people with low incomes to assist them with paying their council tax or their rent. The second type of benefits are social insurance benefits, which are payments that are made if a risky event such as sickness or unemployment occurs, providing sufficient contributions have been made. They also refer to other benefits received by

\footnotetext{
${ }^{4}$ The UK government has recently announced plans to simplify the benefit system by replacing the fairly large number of existing work-related benefits with a single universal credit. This could mean that claimants moving into work keep more of their income than they currently do but may lose benefits if they refuse a job. The government has argued that the current system is extremely complex and expensive to administer.
} 
individuals that are ill or injured, including Statutory Sick Pay, Incapacity Benefit (now known as Employment and Support Allowance) and Industrial Injuries Disablement Benefit. They do not discuss other types of benefits such as Child Benefit, which are not currently means tested. ${ }^{5}$

Before going on to examine the dynamics of social assistance benefit receipt, Cappellari and Jenkins (2009) summarise the main changes that took place to the benefits and tax credits system in the UK between 1991 and 2005. Some of the main changes to take place over this period include the unification of unemployment benefits under the JSA programme in 1996 and the introduction of the Working Families Tax Credit (WFTC) by the new Labour government in 1999. The latter scheme was similar to the Earned Income Tax Credit in the US and replaced the Family Credit system. The WFTC was a welfare-to-work scheme, which was more generous than its predecessor and as a result take-up rates rose dramatically. ${ }^{6}$ For example, Cappellari and Jenkins (2009) report that the percentage of working-age adults receiving tax credits rose from around 3\% in 1997 to $12 \%$ in 2005 . In contrast, the percentage receiving social assistance benefits fell from almost $15 \%$ in 1993 to less than $10 \%$ in 2005 . This decline can not only be explained by the introduction of the tax credit system, which made work more attractive but also because of the tighter job search requirements introduced by the JSA system, which shifted individuals off unemployment benefits (Manning, 2009). Migrant workers living in the UK should be entitled to receive Working Tax Credits (WTC) unless they are subject to immigration control.

\footnotetext{
${ }^{5}$ However, it has recently been announced that child benefit will be withdrawn from households with a higher rate taxpayer from 2013. For further information on type of benefits received by families in the UK, see http://www.direct.gov.uk/en/MoneyTaxAndBenefits/BenefitsTaxCreditsAndOtherSupport/index.htm.

${ }^{6}$ The WFTC was subsequently reformed under the heading of Working Tax Credits so that it also now covers tax credits paid to other groups such as older and disabled workers.
} 
Other types of benefits include those at different ends of the age spectrum. Older people may be entitled to receive the State Pension and Pension Credit to top up their income but these are not so important for immigrants given their younger age profile. On the other hand, Child Benefit is a tax-free payment which is generally available to immigrants, amounting to $£ 18.80$ per week for the eldest child and $£ 12.55$ a week for other children in 2008-9. ${ }^{7}$ Many migrant workers with children should also be entitled to receive Child Tax Credit (CTC), in addition to WTC. CTC is a meanstested allowance for parents and carers of young people who are still in full-time education.

\section{Background Statistics on Welfare Participation by Immigrants in the UK}

As discussed in Section 2, the UK experienced huge migration flows from the EUA8 in the immediate aftermath of EU enlargement. There had been fears that by allowing migrants from the new member states to move to the UK more or less without restriction then there would be large numbers moving to claim welfare benefits rather than to work. Therefore a condition imposed by the UK government on EUA8 migrants was that they had to be resident for a year prior to claiming benefits. In addition, workers were meant to register on the WRS within a month of taking up employment in the UK up until May 2009, although as mentioned previously a fairly high percentage of migrant workers from the EUA8 did not do so. The UK government (through the Home Office, and more recently the UK Border Agency) also began publishing an Accession Monitoring Report in 2004 to track employment statistics, benefit applications and characteristics of EUA8 nationals entering the UK.

\footnotetext{
${ }^{7}$ A discussion of the Child Benefit claims made by EUA8 migrants follows later in the paper.
} 
Information in this report was mainly taken from the WRS database, although it stopped being published after March 2009.

Table 5 reports information from the Accession Monitoring Report on applications for welfare benefits and tax credits by EUA8 nationals in the UK, pooled over May 2004 to March 2009. In line with information provided in Section 2 on employment rates, Table 5 indicates that welfare participation by EUA8 nationals has been low. In total, 42,576 applications for income related benefits were made in the five years following enlargement, with only around a quarter of these allowed to proceed. Data from the final Accession Monitoring Report does however point to the impact of recession since applications for IS and JSA from EUA8 nationals increased from 3,007 in the first quarter of 2008 to 6,732 in the corresponding quarter of 2009. Of these applications, 1,797 were allowed to proceed in the later period, compared to 918 in the previous period. In contrast, much larger numbers of applications were made for child benefit and tax credits. Over 200,000 applications for the former and 100,000 applications for the latter were made over this period, with the majority of applications for each of these claim types approved. In contrast to the data on child benefit applications, WRS data appears to indicate that relatively few EUA8 migrants have brought children with them to the UK. According to these data, only around 76,000 WRS registrants between May 2004 and March 2009 stated that dependent children resided with them in the UK.

There is no information on migrants from other countries in the Accession Monitoring Report so data from other sources needs to be examined to obtain an overall picture of welfare participation by immigrants in the UK, including a comparison with the UK born. This is achieved here by examining several waves of LFS data, which is the main regular source of information on the UK labour market. 
In particular, the LFS contains details on over 50,000 households in each quarter. Households remain in the survey for five waves but only those in their first wave of interviews are included in the subsequent analysis to avoid double counting. Wave 1 interviews also take place in person rather than over the telephone and achieve higher response rates than other waves, either because of sample attrition or for immigrants who only stay in the UK for a short time. Wave 1 information is pooled from the first quarter of 2004 until the fourth quarter of 2009. The sample is also restricted to those aged between 18 and 59. ${ }^{8}$ The sample also excludes immigrants interviewed in the same year that they entered the UK because of the restrictions on the ability of EUA8 migrants to claim benefits in the year they arrive in the UK.

Given its relatively large sample size, the LFS has been used fairly widely to analyse how immigrants have performed in the UK labour market (Drinkwater et al., 2009; Dustmann and Fabbri, 2005; Wheatley Price, 2001). Moreover, the LFS contains detailed information on immigrants country of birth and time of arrival in the UK. The LFS questionnaire also asks respondents to give details on a wide range of their socio-economic circumstances, some of which can be used as control variables in econometric analysis. As a result of the advantages provided by the LFS, this is the data source that will be used in the remainder of the paper. However, it should also be noted that the LFS is likely to under-sample immigrants, especially those moving for only a short period of time, because it generally excludes individuals living in communal establishments and those who have been resident in their household for under 6 months. Furthermore, given that the population weights used in the LFS take

\footnotetext{
${ }^{8}$ The sample of BHPS data used by Cappellari and Jenkins (2009) is based on individuals aged between 25 and 59. They impose an upper age limit because the retirement age for females is 60 in the UK and a lower age limit because of the complications associated with education and training. However, given that around 40\% of recent immigrants are aged between 18 and 24, the lower cut-off age applied here is 18 . However, all full-time students are excluded from the subsequent analysis.
} 
no account of country of birth, the tables presented in the remainder of the paper are based on unweighted data.

In terms of obtaining information on welfare participation, the LFS firstly asks respondents whether they claim any state benefits or tax credits. Those answering this question positively are then further probed on the type of benefit that they claim. Nine different types of benefits are identified: Unemployment Benefits/NI Credits; IS (not as unemployed person); Sickness or Disability Benefits; State Pension; Family Related Benefits (excluding Child Benefit and Tax Credits); Child Benefit; Housing/Council Tax Rebate; Tax Credits and Other Benefits. ${ }^{9}$ Again, those indicating that they claim a certain type of benefit are then asked to be more specific on the type they have claimed for such as whether the IS claim relates to being a sick person, a pensioner, a lone parent or for some other reason. In contrast to other datasets, such as the BHPS, the LFS asks respondents about the claiming of benefits rather than whether they receive them.

Although the LFS has not been extensively used to examine welfare participation by immigrants, a couple of studies have used the questions on whether benefits and tax credits are claimed in order to estimate the fiscal impact of immigration for the UK. Using the LFS for 1999, Gott and Johnson (2002) report that immigrants as a whole are more likely to claim social benefits in comparison to natives, apart from age related ones such as sickness or disability benefits and the state pension. The differences they show are not that large though, with the largest variation seen in terms of child benefit claims, which were made by around $19 \%$ of immigrants and $16 \%$ of natives aged between 16 and 69. Dustmann et al. (2009) analyse differences in benefits or tax credit claims between EUA8 migrants and

\footnotetext{
${ }^{9}$ Unemployment benefits include both income- and contribution based JSA.
} 
natives. They find that claims vary considerably by gender but that EUA8 migrants were far less likely to claim benefits, especially when females are considered. In particular, 24\% of EUA8 migrant females claimed benefits over the period from the second quarter of 2004 to the first quarter of 2009 compared to 55\% of native females. The corresponding figures for males were $12 \%$ and $24 \%$. Even after controlling for the different demographic characteristics of the two groups, Dustmann et al. (2009) still find that EUA8 migrants would be 13\% less likely to claim benefits and $28 \%$ less likely to live in social housing.

Prior to undertaking any econometric analysis in this paper, it is interesting to observe how claimancy rates vary by types of benefits between different immigrant groups, and also in comparison to the UK born. This is particularly useful since the above mentioned studies using the LFS focus on either immigrants as a whole or a specific group of migrants. Dustmann et al. (2009) only examine benefit claims as a whole, whilst Tax Credits were not captured in the data analysed by Gott and Johnson (2002). The percentage in each group claiming different types of benefits is reported for males and females in Table 6, as well as the percentage claiming Tax Credits. The immigrant categories identified in the table as the same ones as those in Table 1 but due to the large volume of EUA8 migration since 2004, the percentage of migrants accounted for by this category has increased considerably. For example, EUA8 migrants accounted for $9 \%$ of the sample considered here compared to an estimated 3\% of the immigrant population in early 2004. It can be seen from Table 5 that the overall picture in terms of benefits is not that different between immigrants as a whole and natives.

However, the summary figures conceal large differences by gender, immigrant group and type of benefit claimed. Firstly, the percentage of immigrant males 
claiming any sort of benefit is 3 percentage points higher than the corresponding figure for natives, whereas it is around 4 percentage points lower for immigrant females. For males, Asian immigrants are by far the most likely to claim benefits, followed by Africans and Other Europeans. The lowest benefit claimancy rates are observed for Australian and EUA8 males. These two groups share some similar some characteristics in that they tend to be young and reside in the UK for short periods for work and also for lifestyle reasons. ${ }^{10}$ Clark and Drinkwater (2008) and Dustmann and Weiss (2007) discuss short term migration in relation to the UK in greater detail. In contrast, UK born females are most likely to claim benefits, with EUA8 and Australian migrants having the lowest rates. The relatively low proportion of EUA8 migrants claiming benefits is particularly interesting and is obviously related to their high employment rates, as highlighted in Table 4. However, it should also be noted that many recent EUA8 migrants to the UK, especially Poles, possess only limited English language skills and partly as a result have found only low paid work (Drinkwater et al., 2009). In spite of this, their rates of claiming benefits remain low and this will be further investigated using econometric analysis in the next section, focusing particularly on the role of socio-economic characteristics. Unfortunately, the LFS does not collect systematic information on English language ability but ad hoc questions which appear in occasional quarters confirm the relative lack of such skills possessed by a fairly high proportion on EUA8 migrants (Clark and Drinkwater, 2008).

Turning to the types of benefits claimed, the patterns are similar to the combined figures for males and females reported by Gott and Johnson (2002) for all immigrants compared to the UK born. This is in spite of the large changes in UK immigration

\footnotetext{
${ }^{10}$ See Table A1 in the Appendix for means of some key variables in the sample. This indicates that EUA8 and Australasian migrants are youngest on average. Both of these groups also have relatively levels of education.
} 
seen since 1999. In comparison to the statistics presented by Gott and Johnson (2002), Table 6 excludes data on individuals claiming the state pension and other family related benefits. This is because the number of individuals in the sample claiming these benefits is very small. For the former, this is because of the imposed upper age limit of 59, as opposed to the 69 used by Gott and Johnson. For the latter, it is likely that family related benefits have been replaced by tax credits, which came into existence in 1999. The table highlights the high take-up rates for tax credits, as also shown by Cappellari and Jenkins (2009). Some other noteworthy observations include the small percentage claiming unemployment related benefits for both natives and immigrants, given the low levels of unemployment seen in the UK until towards the end of the period under consideration. Again, EUA8 and Australasian migrants are least likely to claim benefits both for males and females. These groups also have the lowest claimancy rates for income support but there is slightly more variation for income support claims for the other groups. This is particularly the case for females, where more than $10 \%$ of Other European and African females claim income support. Immigrant males are more likely to claim child benefit than natives, especially Asians. This may be because of cultural reasons where males from certain groups register for such benefits. On the other hand, native females are most likely to claim child benefits. Finally, the patterns observed for other employment benefits are preserved for sickness and housing benefit in that EUA8 and Australasian migrants are least likely to claim such benefits.

\section{Econometric Analysis of Benefit and Tax Credit Claims by Immigrants}

In order to take account of the influence of potentially important socio-economic characteristics in determining differences in benefit claims between immigrants and 
natives, a series of probit models have been estimated. The first set of models use the whole sample, and are estimated separately by gender. These models include a dummy variable for each immigrant group, measured relative to the UK born. Table 7 contains some selected estimates from the probit equations by reporting marginal effects and the corresponding significance levels for the immigrant group dummies. Models have been estimated for all of the types of benefits and tax credits reported in Table 6, as well as for the overall measure of any benefit claim. The specifications of the probit models are similar to those adopted by Barrett and McCarthy (2008) and Dustmann et al. (2009), who control for age, marital status, education and children in the household. In common with Dustmann et al. (2009), age is included in quadratic form, three levels of education (high, medium and low) are identified on the basis of the time that the respondent left full-time education and children relates to the number of dependents under 19 in the household. In addition, spatial and time effects are captured through the inclusion of regional and year of interview dummies and a nonwhite dummy is also added to establish whether ethnic minorities suffer from disadvantage, possibly as a result of discrimination. Table A1 in the Appendix contains the means of some of the key explanatory variables for each of the immigrant groups.

On viewing Table 7 it can be seen that some of the broad patterns reported in Table 6 in terms of the participation by immigrant groups in the welfare system are preserved after controlling for differences in personal characteristics. For example, immigrant males are more likely to claim any benefits than natives but that this picture is reversed for all female immigrant groups, with the exception of those born in Africa. For males, however, taking account of characteristics does have an impact on the relative probability of claiming benefits for some of the immigrant groups. This 
is most noticeable for EUA8 migrants, who are 4 percentage points more likely to claim benefits than the UK born according to the probit estimates compared to the 5 percentage points lower benefit claimancy rate in the raw statistics. Closer inspection of these differences reveals that this is almost entirely due to the impact of the higher levels of education possessed by EUA8 migrants in comparison to natives, and to a lesser extent their younger age profile. More specifically, removing these controls from the equation would imply that EUA8 migrants would be 4 percentage points less likely to claim benefits than natives, which is close to the difference observed in the raw statistics. ${ }^{11}$ Controlling for socio-economic characteristics also means that EU14 migrants are more likely to claim benefits than natives, whilst the only male groups who are less likely to claim are those born in Australasia and the Americas. The large difference in the rates of claiming benefits between native and EUA8 females observed in Table 6 is reduced in the probit estimates but not to such a great extent.

Table 7 also reports the marginal effects for claiming individual benefits for each of the migrant groups relative to the UK born. This comparison reveals some interesting findings including that EUA8 males are significantly less likely to claim unemployment related, IS and sickness benefits but are significantly more likely to claim child benefits and tax credits. Given the higher percentage of claimants on the latter type of welfare schemes, this produces the higher overall likelihood of claiming any type of benefit for EUA8 males reported earlier. The relatively low levels of outof-work related benefits and the high levels of child benefit and tax credit claims is also consistent with the figures reported in the Accession Monitoring Report. In contrast, EUA8 females are far less likely to claim child benefit than the UK born, despite Table A1 reporting that a higher proportion of EUA8 females are married and

\footnotetext{
${ }^{11}$ Dustmann et al. (2009) also find that differences in the probability of claiming benefits between EUA8 migrants and natives fall dramatically after age and education are included in their econometric models.
} 
have dependent children relative to their male counterparts. This accords with the large discrepancy between the number of WRS registrants and child benefit claims highlighted in the Accession Monitoring Report, as well as reports that many Polish migrants claim child benefit for children living in Poland. Estimates suggest that child benefit claims made by Poles for children not in the UK amounted to more than $£ 21$ million per annum (Daily Mail Online, $29^{\text {th }}$ January 2008). Such claims are possible under EU regulations and the intensity of claims has been so high because of the difference between the generosity of child benefit in the UK and the EUA8. For example, all parents were entitled to receive $£ 78.43$ per month for first born children in the UK compared to an estimated $£ 13.18$ in Poland (Daily Mail Online, 29 ${ }^{\text {th }}$ January 2008). Similar patterns are observed for tax credit claims since the marginal effect for EUA8 migrant females is very close to zero, whereas EUA8 males are 8 percentage points more likely to make such claims compared to natives.

Otherwise, Table 7 reports rather mixed results in terms of claiming different types of benefits. One consistent finding is that females from all immigrant groups are significantly less likely than native females to claim child benefit. This may be due to there being more of a tradition amongst UK born females in making this type of claim in comparison to females from abroad, where the male in the household may be more likely to lodge the claim. This is possible given that Table A1 does not reveal very large differences between males and females in terms of the distribution of dependent children. Similarly, immigrant females, apart from those from the EUA8, are significantly less likely to claim tax credits than their native born counterparts. Finally, Other Europeans have high levels of IS and housing/council tax benefit claims, both for males and females. 
Given the differences in the types of benefits claimed by the migrant groups, Table 7 also contains estimates of social assistance benefit claims. As noted in Section 3, this definition includes unemployment related benefits, IS and housing and council tax benefits and are often termed as welfare benefits. This measure would thus appear to be a useful categorisation of similar types of benefits. The estimates shown in the table indicate that Australasian males are least likely to claim social assistance benefits and Other Europeans the most likely. EUA8 males are just over 1 percentage point less likely to claim such benefits than the UK born after controlling for socioeconomic characteristics but this is only significant at the $10 \%$ level. Similar patterns are also revealed for females, especially for Other European and Australasian migrants. The marginal effect for EUA8 migrant females is virtually zero, however the influence of age and education is again apparent since excluding these variables would result in a 4 percentage point lower incidence of social assistance benefit claims in comparison to natives.

The full results from the pooled model used to estimate the probability of receiving social assistance benefits are reported in Table A2 in the Appendix. Some of more noteworthy observations include the sharp increase in social assistance benefit claims in 2009 (the base category), which clearly demonstrates the influence of recession in this year. This is particularly noticeable for males since the percentage claiming social assistance benefits was 5 percentage points higher than it had been in the previous five years, a period over which the unemployment rate had been very stable. Social assistance benefit claims vary by region, with the highest rates witnessed in the North East (the base category) for males and in London for females and the lowest rates in the South East and Eastern regions. Again these findings mirror the corresponding unemployment rates. Higher levels of education reduce the 
probability of claiming social assistance benefits, especially for females, and ethnic minority individuals are around 5 percentage points more likely than whites to make such claims. Large marginal effects are reported on the married dummy for both males and females. This is partly because controls for dependent children have been included and when this effect is taken into account it is found that married people are far less likely to claim social assistance benefits.

Separate estimates are reported for social assistance benefit claims for each immigrant group, apart from Australasians, by gender in Table 8. The reason why the estimates for Australasian migrants have not been included in the table is because this group has the smallest sample size and also the lowest incidence of claiming social assistance benefits. These two effects combine to produce extremely small and insignificant marginal effects, which require little comment. The specifications are similar to those estimated in the pooled model apart from for each migrant group, additional controls have been added for years since migration and its square to capture possible assimilation effects.

The table indicates that higher levels of education are associated with a lower incidence of claiming social assistance benefits for virtually every group. The effect of education is also greater for most migrant groups for females than it is for males and is highest of all for females from other parts of Europe. Females with low and medium levels of education from these countries are respectively 21 and 11 percentage points more likely to claim social assistance benefits in comparison to highly educated females. The impact of education is smallest for EUA8 migrants. In particular, compared to individuals with high levels of education, the difference between those with low levels of education is only significant at the $10 \%$ level and there are no significant differences for those with medium levels of education for both 
males and females. These findings may be explained by the fact that recent EUA8 migrants in general have very high employment rates, as shown in Table 4, as well as a large percentage with high levels of education, as measured by the age the individual left full-time education, which can be seen from Table A1.

Age has a varying effect on social assistance benefit claims for different groups. For some, such as EUA8 males, the influence of age is initially decreasing and then increasing. In contrast, for Asian males social assistance benefit claims are initially increasing in age before age begins to have a decreasing impact. Whilst for African males, age has a positive and increasing impact on the probability of claiming social assistance benefits. Age has a similarly mixed effect for the female immigrant groups, with even different patterns and significance levels compared to the results shown for males. In terms of the other influence entered as a quadratic, social assistance benefit claims initially increase with years since migration but at a decreasing rate. This is true for all groups, except for Asian males, although there is some variation in the impact of years since migration. For males, the marginal effect of years since migration is greatest for EUA8 migrants. However, EUA8 migrants have very different arrival patterns compared to other migrant groups since the vast majority have entered the UK following enlargement in 2004. This can be verified with reference to Table A1 since mean years since migration are by far the lowest for EUA8 migrants, with males having been in the UK for less than 4 years on average compared to the next lowest average of around 15 years for Australasians. As a result, the turning point for years since migration for EUA8 males is 11 years in the UK, which is far less than it is for EU14 (25 years) and American (27 years) migrants but greater than it is for either Other European or African migrants. This pattern is also replicated for females. 
Dependent children increase social assistance benefit claims for the majority of migrant groups, especially for females, although the marginal effects are not always significant. The impact of dependent children is largest for African females. The influence of dependent children is weakest for females born in the EUA8, for whom individuals living in households with no dependent children are not significantly different from those where there are 3 or more. As noted in the discussion of Table A2, the effect of being married is strongly negative once dependent children are taken into account, although EUA8 migrants are again the exception to this. Nonwhites are more likely to claim social assistance benefits for nearly all groups. However, the marginal effects are not always significant because of either a high proportion on ethnic minorities (for Asians) or a low proportion (for EUA8 and Other Europeans). ${ }^{12}$ Sample variation is also likely to explain the positive impact attached to this dummy variable for EUA8 males, which is the only group where a negative effect is not observed. Thus the findings on the impact of ethnicity on social assistance benefit claims indicate that non-white migrants are dis-proproportionally more likely to claim welfare benefits, and that an element of discrimination cannot be ruled out given the consistent findings across the groups.

As mentioned previously, the LFS does not routinely collect information on English language ability, which is unfortunate given the importance of this attribute for many immigrant outcomes. However, a limited range of questions related to the English language were asked in the third quarter of 2009. The first question of relevance is the first language spoken at home and if the response to this question was other than English then the respondent was also asked whether they had experienced language difficulties in finding or keeping a job. The relatively small sample of

\footnotetext{
${ }^{12}$ See Table A1 for details. It has only been possible to combine individuals with a non-white background using a single dummy because of the high proportion from the same broad ethnic origin for the majority of the migrant groups.
} 
immigrants answering these questions prevents any detailed econometric investigation, but basic analysis of these questions in relation to social assistance claims reveals some interesting findings. In particular, only around 8\% of immigrants who spoke English as a first language at home claimed social assistance benefits, whereas this was over 5 percentage points higher for those mainly speaking another language at home. Furthermore, amongst this latter category of immigrants, the incidence of social assistance claims was again more than 5 percentage points higher for those who had experienced a language difficulty in finding or keeping a job compared to those who had experienced no such difficulty.

\section{Conclusion}

Possibly the main conclusion of the paper is that for the UK at least, it is very difficult to generalise on the issue of welfare participation by immigrants. This is because social welfare claims vary considerably by immigrant group as well as by the types of benefits that are claimed. Australasian and EUA8 migrants are the least likely to claim welfare benefits but this is to some extent explained by the characteristics of individuals from these groups, especially for those from accession countries. EUA8 migrants also differ from the other groups in the sense that they typically stay in the UK on a short term basis. As a result, the majority of EUA8 migrants have only been in the UK for a relatively short time and many of those with the most irregular migration patterns are unlikely to participate in the UK benefits system at all. However, EUA8 migrants, especially males, are far more likely to claim child benefit and tax credits, even if their children do not actually reside with them in the UK. In contrast, much higher rates of welfare benefit claims are made by other groups, especially migrants from Asia and other parts of Europe. The cultural explanations 
discussed in previous research may account for some of this, especially for the former group (Clark and Drinkwater, 2009), but further investigation of other findings such as the high levels of social assistance benefit claims by the latter group is also required.

Neither is the relationship between immigrants and welfare participation a static one. In particular, the UK welfare state will certainly be heavily affected by the recent recession and the subsequent impact this had on government finances. This can be seen by the higher social assistance benefit claims in comparison to previous years observed in 2009 in both the overall LFS data and in the administrative records for EUA8 migrants. However, it is unclear how the relative levels of welfare participation by immigrants in the coming years. It is likely that migration flows from some countries, such as the EUA8, will further slow and even reverse quite substantially if the UK labour market remains sluggish, although not all migrants who have difficulty in finding work will return to their home countries. Moreover, given the current pressures on government finances and the desire to reduce debt levels, it could be that access to the welfare state will be further restricted for some groups, including for immigrants. With regards to recent policy changes, it is also too soon to detect the impact of the points-based system of immigration, which was introduced in the UK in 2008. The selection of migrants from outside of the EU on the basis of certain characteristics might also generate a change in the relative rankings of immigrant groups in terms of their propensity to claim welfare benefits. On the other hand, this may be counter-balanced by a further tightening of UK immigration policy, which is likely given the future introduction of quotas for migrants from non-EU countries.

In terms of other policy implications, then it has been found that investments in human capital are strongly associated with lower levels of benefit claims. The 
econometric estimates reveal that those with lower levels of education are far more likely to claim social assistance benefits amongst all migrant groups, although the educational differences are smallest for EUA8 migrants. Furthermore, the limited analysis that has been undertaken with respect to language indicates that much higher levels of social assistance claims are observed for migrants with weaker English language skills. These findings suggest that government policies to enhance human capital formation amongst migrants should reduce the dependency on social assistance benefits. The effectiveness of such policies should also be enhanced by the recent introduction of a points-based system for non-EU migrants, which seeks to skew immigration from outside of the EU towards more highly skilled individuals. 


\section{References}

Baker, M. and Benjamin, D. (1995), “The Receipt of Transfer Payments by Immigrants to Canada”, Journal of Human Resources, 30, 650-76.

Barrett, A. and McCarthy, Y. (2008), "Immigrants and Welfare Programmes: Exploring the Interactions between Immigrant Characteristics, Immigrant Welfare Dependence and Welfare Policy", Oxford Review of Economic Policy, 24, 542-59.

Blanchflower, D. and Lawton, H. (2009), “The Impact of the Recent Expansion of the EU on the UK Labour Market” in M. Kahanec and K. Zimmermann (eds.), EU Labor Markets After Post-Enlargement Migration, Springer.

Blume, K. and Verner, M. (2007), "Welfare Dependency Among Danish Immigrants” European Journal of Political Economy, 23, 453-71.

Borjas, G. and Hilton, L. (1996), “Immigration and the Welfare State: Immigrant Participation in Means-Tests Entitlement Programs”, Quarterly Journal of Economics, 111, 574-604.

Cappellari, L. And Jenkins, S. P. (2009), “The Dynamics of Social Assistance Beenfit Receipt in Britain”, IZA Discussion Paper No. 4457.

Clark, K. and Drinkwater, S. (2008), “The Labour Market Performance of Recent Migrants”, Oxford Review of Economic Policy, 24, 495-516

Clark, K. and Drinkwater, S. (2010), “Dynamics and Diversity: Ethnic Employment Differences in England and Wales, 1991 - 2001”, Research in Labor Economics, 29, 299-333.

Drinkwater, S., Eade, J. and Garapich, M. (2009), “Poles Apart? EU Enlargement and the Labour Market Outcomes of Immigrants in the UK”, International Migration, 47, 161-90. 
Dustmann, C. and Fabbri, F. (2005), “Immigrants in the British Labour Market”, Fiscal Studies, 26, 423-70.

Dustmann, C., Frattini, T. and Hills, C. (2009), “Assessing the Fiscal Costs and Benefits of A8 Migration to the UK”, CReAM Discussion Paper No. 18/09, University College London.

Dustmann, C. and Weiss, Y. (2007), "Return Migration: Theory and Empirical Evidence from the UK”, British Journal of Industrial Relations, 45, 236-56.

Gott, C. and Johnson, K. (2002), “The Migrant Population in the UK: Fiscal Effects”, Research, Development and Statistical Directorate Occasional Paper No. 77, Home Office, London.

Gustman, A. and Steinmeier, T. (2000), "Social Security Benefits of Immigrants and the US Born”, in G. Borjas (ed.) Issues in the Economics of Immigration, University of Chicago Press, Chicago.

Hansen, J. and Lofstram, M. (2003), “Immigrant Assimilation and Welfare Participation”, Journal of Human Resources, 38, 74-98.

Lemos, S. and Portes, J. (2008), "New Labour? The Impact of Migration from the New European Union Member States on Native Workers”, IZA Discussion Paper No. 3756.

Manning, A. (2009), "You Can’t Always Get What You Want: The Impact of UK Jobseeker’s Allowance”, Labour Economics, 16, 239-50.

Oxford Economics (2009), "Regional Economic Performance: A Migration Perspective”, Economics Paper 4, Department of Communities and Local Government.

Pekkala Kerr, S. and Kerr, W. (2009), "Economic Impacts of Immigration: A Survey”, HBS Working Paper No. 09-013, Harvard University. 
UK Border Agency (2009), Accession Monitoring Report, May 2004-March 2009, A joint online report between the UK Border Agency, Department for Work and Pensions, HM Revenue and Customs and Communities and Local Government.

Wheatley Price, S. (2001), “The Employment Adjustment of Immigrants in England”, Journal of Population Economics, 14, 193-220. 
Table 1: Period of Arrival in the UK (in percentages) for Main Immigrant Groups, 2004 Quarter 1

\begin{tabular}{lcccccccc}
\hline \hline & Pre 1950 & 1950s & 1960s & 1970s & 1980s & 1990s & Post 1999 & Estimated Population \\
\hline EU14 & 10.2 & 15.0 & 13.9 & 11.0 & 11.9 & 22.0 & 16.1 & $1,228,037$ \\
EUA8 & 25.0 & 1.9 & 3.0 & 5.2 & 3.7 & 28.6 & 32.6 & 159,275 \\
Other Europe & 6.3 & 8.0 & 13.4 & 7.0 & 9.8 & 35.2 & 20.3 & 367,433 \\
Asia & 2.9 & 4.2 & 14.1 & 15.1 & 16.2 & 22.9 & 24.7 & $1,600,230$ \\
Americas & 3.4 & 8.3 & 26.1 & 11.1 & 7.2 & 23.1 & 20.9 & 572,017 \\
Australasia & 4.8 & 2.9 & 6.3 & 10.2 & 10.6 & 28.7 & 36.6 & 151,756 \\
Africa & 0.9 & 2.4 & 9.6 & 17.5 & 14.2 & 30.6 & 24.8 & 951,493 \\
\hline All immigrants & 5.4 & 7.1 & 13.9 & 13.0 & 12.7 & 25.4 & 22.5 & $5,030,241$ \\
\hline \hline
\end{tabular}

Source: Labour Force Survey 
Figure 1: NINO Registrations by Adult Overseas Nationals Entering the UK by Financial Year

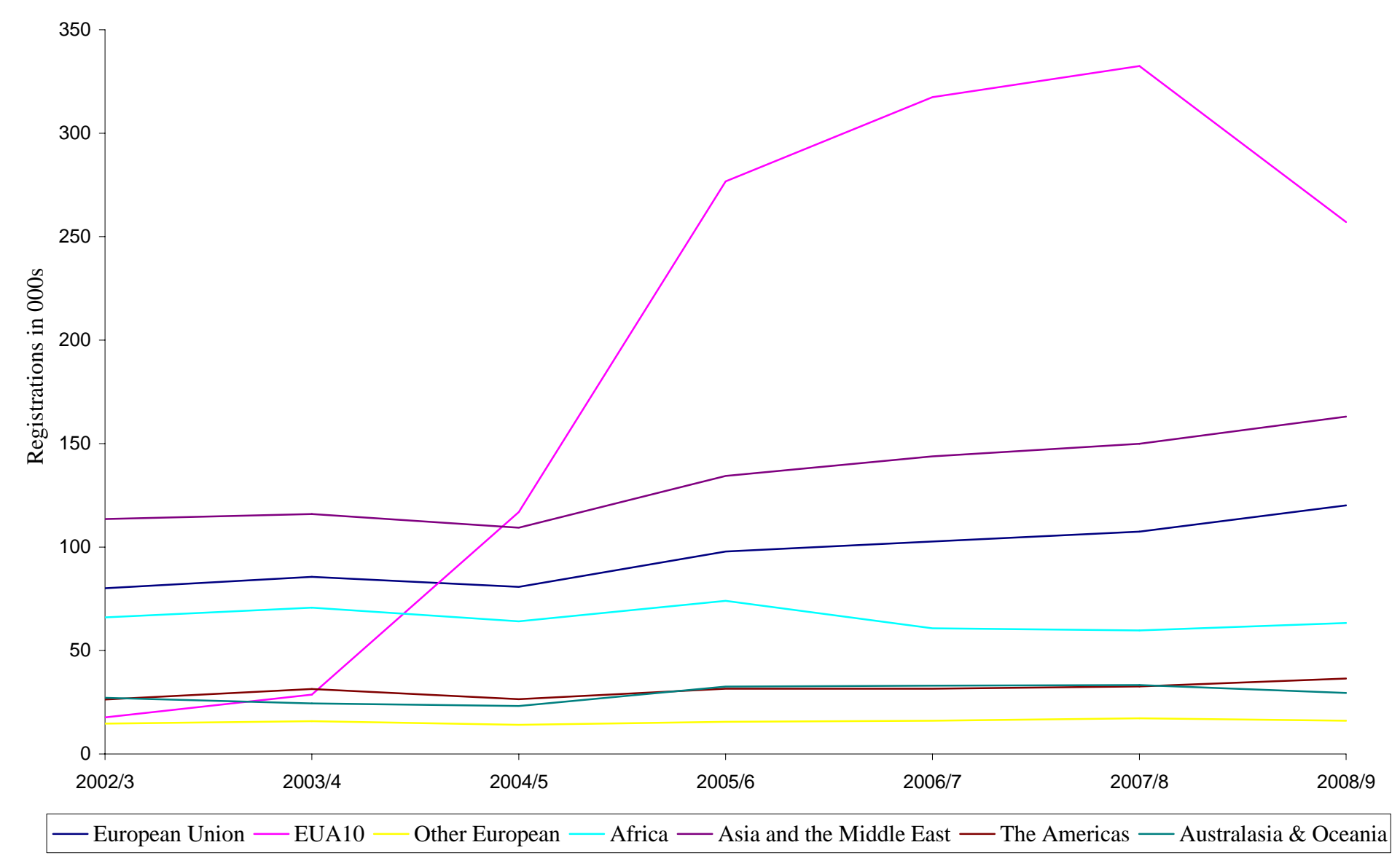

Source: Department of Work and Pensions 
Table 2: Characteristics of Adult Overseas Nationals Registering for a NINo

\begin{tabular}{lccccccc}
\hline \hline & $\mathbf{2 0 0 2 / 3}$ & $\mathbf{2 0 0 3 / 4}$ & $\mathbf{2 0 0 4 / 5}$ & $\mathbf{2 0 0 5 / 6}$ & $\mathbf{2 0 0 6 / 7}$ & $\mathbf{2 0 0 7 / 8}$ & $\mathbf{2 0 0 8 / 9}$ \\
\hline \% Male & 51.46 & 50.07 & 52.49 & 54.20 & 53.50 & 53.87 & 52.52 \\
\hdashline \% Aged $<18$ & 1.36 & 1.39 & 0.90 & 0.76 & 0.83 & 1.19 & 1.39 \\
\% Aged 18-24 & 30.92 & 31.49 & 34.24 & 36.30 & 37.07 & 38.18 & 38.71 \\
\% Aged 25-34 & 48.46 & 47.07 & 46.33 & 44.91 & 43.79 & 41.98 & 40.76 \\
\% Aged 35-44 & 13.68 & 14.11 & 12.62 & 11.97 & 11.95 & 12.04 & 12.09 \\
\% Aged 45-54 & 4.45 & 4.79 & 4.80 & 4.98 & 5.22 & 5.36 & 5.47 \\
\% Aged 55+ & 1.14 & 1.14 & 1.11 & 1.08 & 1.13 & 1.25 & 1.59 \\
\% Polish & 1.70 & 3.01 & 14.04 & 25.80 & 31.23 & 28.74 & 19.58 \\
\% Other EUA8 & 1.58 & 2.30 & 10.72 & 14.81 & 12.54 & 11.35 & 11.78 \\
\% India & 7.16 & 8.44 & 7.46 & 6.93 & 6.92 & 6.79 & 8.66 \\
\% Other Countries & 89.56 & 86.25 & 67.79 & 52.47 & 49.31 & 53.13 & 59.98 \\
\hline Total (in thousands) & 346.23 & 373.5 & 435.35 & 663.06 & 705.84 & 733.09 & 686.11 \\
\hline \hline
\end{tabular}

Source: Department of Work and Pensions 
Table 3: Employment Levels in Thousands by Country of Birth

\begin{tabular}{lccccccc}
\hline \hline & $\mathbf{2 0 0 3}$ & $\mathbf{2 0 0 4}$ & $\mathbf{2 0 0 5}$ & $\mathbf{2 0 0 6}$ & $\mathbf{2 0 0 7}$ & $\mathbf{2 0 0 8}$ & $\mathbf{2 0 0 9}$ \\
\hline UK born & 25,738 & 25,852 & 26,022 & 25,917 & 25,815 & 25,772 & 25,315 \\
Non-UK born & 2,591 & 2,728 & 2,935 & 3,254 & 3,547 & 3,722 & 3,677 \\
\hline EU14 & 631 & 616 & 629 & 617 & 680 & 662 & 673 \\
EUA8 & 47 & 97 & 191 & 304 & 442 & 515 & 500 \\
USA & 90 & 78 & 90 & 107 & 95 & 79 & 95 \\
South Africa & 139 & 132 & 134 & 151 & 136 & 160 & 137 \\
Rest of Africa & 441 & 455 & 497 & 526 & 555 & 581 & 543 \\
Australia and New Zealand & 128 & 134 & 128 & 135 & 135 & 131 & 134 \\
India & 227 & 256 & 287 & 326 & 302 & 345 & 343 \\
Pakistan and Bangladesh & 175 & 212 & 188 & 206 & 252 & 261 & 236 \\
Other & 713 & 748 & 791 & 882 & 950 & 988 & 1016 \\
\hline Total & 28,331 & 28,583 & 28,960 & 29,176 & 29,370 & 29,499 & 29,003 \\
\hline \hline
\end{tabular}

Source: ONS

Notes: Relates to people aged 16 and over. Series shown is taken from the third quarter (July to September) of each year and is not seasonally adjusted. 
Table 4: Employment Rates by Country of Birth

\begin{tabular}{lccccccc}
\hline \hline & 2003 & 2004 & 2005 & 2006 & 2007 & 2008 & 2009 \\
\hline UK born & 76.0 & 76.0 & 76.2 & 75.8 & 75.8 & 75.5 & 73.6 \\
Non-UK born & 65.7 & 66.4 & 66.7 & 68.3 & 68.9 & 69.2 & 67.3 \\
\hline EU14 & 73.2 & 73.2 & 74.5 & 77.0 & 75.4 & 75.8 & 73.5 \\
EUA8 & 61.6 & 75.3 & 81.0 & 81.5 & 83.1 & 84.2 & 82.6 \\
USA & 72.4 & 70.5 & 76.7 & 74.0 & 73.4 & 67.5 & 71.7 \\
South Africa & 85.6 & 81.8 & 78.5 & 83.9 & 84.8 & 84.9 & 77.5 \\
Rest of Africa & 65.7 & 64.4 & 65.3 & 64.3 & 66.7 & 64.9 & 59.5 \\
Australia and New Zealand & 87.4 & 91.7 & 87.6 & 84.8 & 86.6 & 83.1 & 85.8 \\
India & 67.4 & 68.3 & 70.2 & 69.8 & 68.8 & 71.4 & 70.4 \\
Pakistan and Bangladesh & 42.5 & 47.9 & 41.9 & 46.1 & 47.8 & 49.1 & 45.2 \\
\hline Total & 74.9 & 75.0 & 75.1 & 74.9 & 74.8 & 74.6 & 72.7 \\
\hline \hline
\end{tabular}

Source: ONS.

Notes: Relates to men aged 16 to 64 and females aged 16 to 59. Series shown is taken from the third quarter (July to September) of each year and is not seasonally adjusted. 
Table 5: Benefits and Tax Credits Receipts by EUA8 Migrants, May 2004-March 2009

\begin{tabular}{|c|c|c|c|}
\hline & Disallowed & Allowed to Proceed & Total \\
\hline Income Support & 11,497 & 2,492 & 13,989 \\
\hline Employment \& Support Allowance & 219 & 113 & 332 \\
\hline Jobseekers Allowance (Income based) & 19,589 & 7,797 & 27,366 \\
\hline State Pension Credit & 531 & 358 & 889 \\
\hline \multirow[t]{2}{*}{ Total tax funded income related benefits } & 31,816 & 10,760 & 42,576 \\
\hline & Rejected/Terminated & Approved & Total \\
\hline Child Benefit & 42,099 & 136,327 & 206,853 \\
\hline Tax Credits & 12,218 & 78,261 & 116,040 \\
\hline
\end{tabular}

Source: UK Borders Agency.

Notes: Figures for Employment and Support Allowance (income-related) only provided for 2009 Q1. Decisions have not been made on some of the applications for Tax Credits and Child Benefit, mainly due to the need for supplementary enquiries to establish the claimant's right to reside. 
Table 6: Percentage Claiming Social Benefits and Tax Credits by Immigrant Group

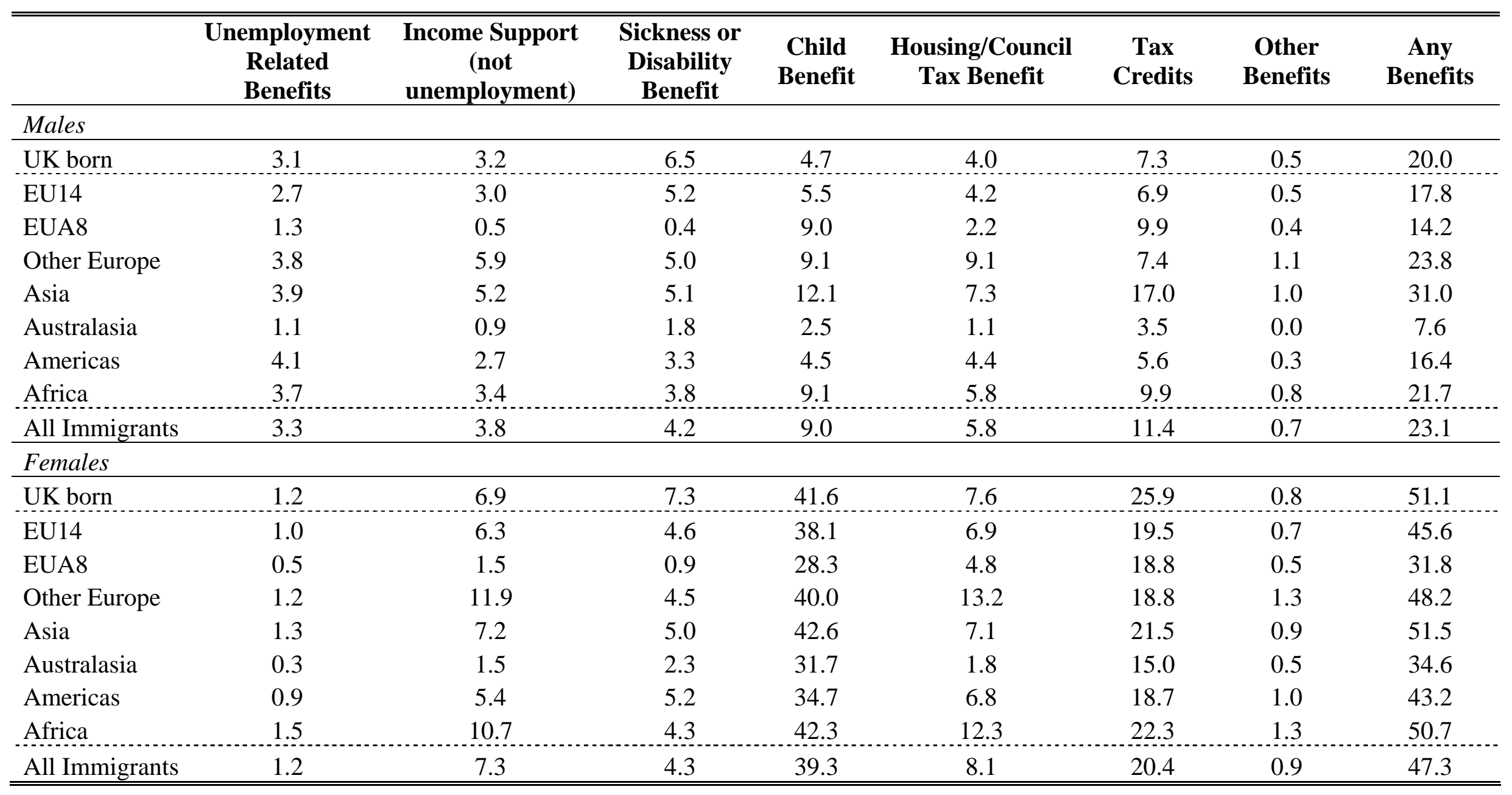


Table 7: Marginal Effects for Immigrant Groups from Probit Estimates of Social Benefit and Tax Credit Claims

\begin{tabular}{|c|c|c|c|c|c|c|c|c|c|}
\hline & $\begin{array}{l}\text { Unemp. } \\
\text { Related } \\
\text { Benefits } \\
\end{array}$ & $\begin{array}{c}\text { IS } \\
\text { (not } \\
\text { unemp.) }\end{array}$ & $\begin{array}{c}\text { Sickness or } \\
\text { Disability } \\
\text { Benefit } \\
\end{array}$ & $\begin{array}{l}\text { Child } \\
\text { Benefit }\end{array}$ & $\begin{array}{c}\text { Housing/ } \\
\text { Council Tax } \\
\text { Benefit } \\
\end{array}$ & $\begin{array}{c}\text { Tax } \\
\text { Credits }\end{array}$ & $\begin{array}{c}\text { Other } \\
\text { Benefits }\end{array}$ & $\begin{array}{c}\text { Social } \\
\text { Assistance } \\
\text { Benefits } \\
\end{array}$ & $\begin{array}{c}\text { Any } \\
\text { Benefits }\end{array}$ \\
\hline \multicolumn{10}{|l|}{ Males } \\
\hline EU14 & 0.003 & 0.005 & 0.000 & $0.004^{*}$ & $0.009^{* *}$ & 0.008 & 0.001 & 0.007 & 0.013 \\
\hline EUA8 & $-0.011^{* * *}$ & $-0.013^{* * *}$ & $-0.039^{* * *}$ & $0.038^{* * *}$ & $0.014^{*}$ & $0.062^{* * *}$ & 0.001 & $-0.016^{* *}$ & $0.032^{* *}$ \\
\hline Other Europe & $0.013^{* *}$ & $0.043^{* * *}$ & $0.016^{*}$ & $0.012^{* * *}$ & $0.075^{* * *}$ & 0.004 & $0.007^{* *}$ & $0.095^{* * *}$ & $0.077^{* * *}$ \\
\hline Asia & 0.003 & $0.017^{* * *}$ & 0.005 & $0.007^{* * *}$ & $0.029^{* * *}$ & $0.026^{* * *}$ & $0.003^{* *}$ & $0.034^{* * *}$ & $0.055^{* * *}$ \\
\hline Australasia & $-0.011^{* *}$ & $-0.014^{* * *}$ & $-0.023^{* * *}$ & $-0.006^{* *}$ & $-0.020^{* * *}$ & -0.014 & - & $-0.036^{* * *}$ & $-0.087^{* * *}$ \\
\hline Americas & 0.005 & $-0.007^{* *}$ & $-0.020^{* * *}$ & $-0.004^{* * *}$ & -0.004 & -0.008 & $-0.003^{* *}$ & -0.004 & $-0.035^{* * *}$ \\
\hline Africa & 0.004 & $0.008^{* *}$ & -0.006 & $0.006^{* * *}$ & $0.020^{* * *}$ & 0.008 & 0.001 & $0.017^{* * *}$ & 0.014 \\
\hline \multicolumn{10}{|l|}{ Females } \\
\hline EU14 & 0.000 & $0.008^{* *}$ & $-0.016^{* * *}$ & $-0.060^{* * *}$ & $0.007^{* *}$ & $-0.025^{* * *}$ & -0.000 & $0.008^{*}$ & $-0.053^{* * *}$ \\
\hline EUA8 & $-0.004^{* * *}$ & $-0.019^{* * *}$ & $-0.035^{* * *}$ & $-0.134^{* * *}$ & $0.017^{*}$ & -0.004 & -0.001 & -0.001 & $-0.171^{* * *}$ \\
\hline Other Europe & 0.003 & $0.074^{* * *}$ & 0.001 & $-0.113^{* * *}$ & $0.081^{* * *}$ & $-0.039^{* * *}$ & $0.007^{* *}$ & $0.104^{* * *}$ & $-0.079^{* * *}$ \\
\hline Asia & -0.000 & $0.009^{* * *}$ & -0.005 & $-0.116^{* * *}$ & 0.003 & $-0.057^{* * *}$ & 0.001 & $0.012^{* * *}$ & $-0.134^{* * *}$ \\
\hline Australasia & $-0.005^{* * *}$ & $-0.023^{* * *}$ & $-0.023^{* * *}$ & $-0.101^{* * *}$ & $-0.030^{* * *}$ & $-0.052^{* * *}$ & -0.001 & $-0.045^{* * *}$ & $-0.172^{* * *}$ \\
\hline Americas & $-0.004^{* * *}$ & $-0.009^{* * *}$ & $-0.011^{* *}$ & $-0.087^{* * *}$ & $-0.008^{*}$ & $-0.021^{*}$ & 0.001 & $-0.012^{* *}$ & $-0.102^{* * *}$ \\
\hline Africa & 0.001 & $0.021^{* * *}$ & $-0.011^{* * *}$ & $-0.092^{* * *}$ & $0.028^{* * *}$ & $-0.034^{* * *}$ & 0.002 & $0.034^{* * *}$ & $0.098^{* * *}$ \\
\hline
\end{tabular}

Notes: Controls also included for age, marital status, education, dependent children in household, region, ethnicity and year.

Marginal effects have been calculated at sample means. ${ }^{*} p<0.1 ;{ }^{* *} p<0.05 ;{ }^{* * *} p<0.01$ (two-tailed tests using robust standard errors). 
Table 8: Selected Marginal Effects from Probit Estimates of Social Assistance Claims by Immigrant Group

\begin{tabular}{|c|c|c|c|c|c|c|c|c|c|c|c|c|}
\hline & Age & $\begin{array}{c}\text { Age } \\
\text { sq./100 }\end{array}$ & Married & $\begin{array}{c}\text { Low } \\
\text { Education }\end{array}$ & $\begin{array}{c}\text { Medium } \\
\text { education }\end{array}$ & $\begin{array}{l}\text { Non- } \\
\text { white }\end{array}$ & YSM & $\begin{array}{c}\text { YSMsq. } \\
/ 100\end{array}$ & $\begin{array}{c}\text { No Dep. } \\
\text { Kids } \\
\end{array}$ & $\begin{array}{c}1-2 \\
\text { Dep. Kids } \\
\end{array}$ & $\begin{array}{c}\text { Pseudo } \\
\text { R-sq. }\end{array}$ & $\mathbf{N}$ \\
\hline \multicolumn{13}{|l|}{ Males } \\
\hline UK born & $-0.001^{* *}$ & $0.003^{* * *}$ & $-0.095^{* * *}$ & $0.071^{* * *}$ & $0.043^{* * *}$ & $0.056^{* * *}$ & - & - & $-0.033^{* * *}$ & $-0.038^{* * *}$ & 0.103 & 123325 \\
\hline EU14 & -0.003 & $0.006^{*}$ & $-0.056^{* * *}$ & $0.080^{* * *}$ & $0.062^{* * *}$ & $0.092^{* * *}$ & $0.004^{* * *}$ & $-0.007^{* * *}$ & -0.022 & -0.020 & 0.125 & 2469 \\
\hline EUA8 & $-0.004^{* *}$ & $0.005^{* *}$ & $0.010^{*}$ & $0.020^{*}$ & -0.004 & $-0.007^{* *}$ & $0.005^{* * *}$ & $-0.021^{* * *}$ & -0.029 & -0.006 & 0.272 & 1351 \\
\hline Other Europe & -0.006 & 0.012 & $-0.088^{* * *}$ & $0.145^{* * *}$ & 0.039 & $0.049^{*}$ & 0.002 & $-0.010^{*}$ & -0.048 & 0.043 & 0.135 & 1080 \\
\hline Asia & $0.009^{* * *}$ & -0.007 & $-0.094^{* * *}$ & $0.139^{* * *}$ & $0.097^{* * *}$ & $0.025^{*}$ & 0.000 & $-0.004^{*}$ & $-0.052^{* * *}$ & $-0.044^{* * *}$ & 0.093 & 5681 \\
\hline Americas & 0.000 & 0.002 & $-0.066^{* * *}$ & $0.062^{* * *}$ & $0.045^{*}$ & $0.040^{* * *}$ & $0.003^{*}$ & -0.005 & 0.056 & 0.058 & 0.178 & 1192 \\
\hline Africa & $0.006^{*}$ & 0.006 & $-0.062^{* * *}$ & $0.085^{* * *}$ & $0.037^{* * *}$ & $0.040^{* * *}$ & 0.001 & $-0.007^{* *}$ & $-0.037^{* * *}$ & $-0.064^{* * *}$ & 0.107 & 3190 \\
\hline \multicolumn{13}{|l|}{ Females } \\
\hline UK born & $-0.003^{* * *}$ & $0.004^{* * *}$ & $-0.162^{* * *}$ & $0.106^{* * *}$ & $0.076^{* * *}$ & $0.038^{* * *}$ & - & - & $-0.116^{* * *}$ & $-0.047^{* * *}$ & 0.195 & 133152 \\
\hline EU14 & 0.000 & 0.000 & $-0.123^{* * *}$ & $0.128^{* * *}$ & $0.064^{* * *}$ & 0.035 & $0.003^{* * *}$ & $-0.006^{* * *}$ & $-0.103^{* * *}$ & $-0.039^{* * *}$ & 0.240 & 3101 \\
\hline EUA8 & 0.006 & -0.005 & $-0.032^{* * *}$ & $0.053^{* *}$ & $0.020^{* *}$ & 0.008 & 0.002 & -0.005 & $-0.043^{*}$ & 0.007 & 0.149 & 1437 \\
\hline Other Europe & -0.007 & 0.013 & $-0.159^{* * *}$ & $0.205^{* * *}$ & $0.097^{* * *}$ & $0.054^{*}$ & 0.001 & -0.007 & $-0.150^{* * *}$ & -0.016 & 0.203 & 1224 \\
\hline Asia & $0.005^{* *}$ & -0.004 & $-0.180^{* * *}$ & $0.119^{* * *}$ & $0.080^{* * *}$ & 0.010 & $0.003^{* *}$ & $-0.009^{* * *}$ & $-0.067^{* * *}$ & $-0.032^{* * *}$ & 0.134 & 6309 \\
\hline Americas & $-0.007^{* *}$ & $0.009^{* *}$ & $-0.077^{* * *}$ & $0.088^{* * *}$ & $0.040^{* *}$ & $0.027^{* * *}$ & $0.005^{* * *}$ & $-0.009^{* * *}$ & $-0.099^{* * *}$ & $-0.050^{* * *}$ & 0.253 & 1771 \\
\hline Africa & -0.006 & $0.009^{*}$ & $-0.160^{* * *}$ & $0.141^{* * *}$ & $0.046^{* * *}$ & $0.053^{* * *}$ & 0.000 & -0.006 & $-0.175^{* * *}$ & $-0.083^{* * *}$ & 0.208 & 3522 \\
\hline
\end{tabular}

Notes: Reference category for education is high and for dependent children in household is 3 or more. Equations also control for region and year. Marginal effects have been calculated at sample means. ${ }^{*} p<0.1 ;{ }^{* *} p<0.05 ;{ }^{* * *} p<0.01$ (two-tailed tests using robust standard errors). 
Table A1: Means of Key Explanatory Variables by Immigrant Group

\begin{tabular}{lcccccccccc}
\hline \hline & Age & Married & London & $\begin{array}{c}\text { Low } \\
\text { Education }\end{array}$ & $\begin{array}{c}\text { High } \\
\text { education }\end{array}$ & $\begin{array}{c}\text { Non- } \\
\text { white }\end{array}$ & YSM & $\begin{array}{c}\text { No Dep. } \\
\text { Kids }\end{array}$ & $\begin{array}{c}\text { 1-2 } \\
\text { Dep. Kids }\end{array}$ \\
\hline Males & & & & & & & & & & \\
N
\end{tabular}

Note: The means shown in the above table relate to the probit model estimated using any benefits claim as the dependent variable. 
Table A2: Full Probit Estimates for Social Assistance Benefit Claims

\begin{tabular}{|c|c|c|c|c|}
\hline & \multicolumn{2}{|c|}{ Males } & \multicolumn{2}{|c|}{ Females } \\
\hline & $\begin{array}{c}\text { Marginal } \\
\text { Effect }\end{array}$ & $\begin{array}{c}\text { Standard } \\
\text { Error }\end{array}$ & $\begin{array}{c}\text { Marginal } \\
\text { Effect }\end{array}$ & $\begin{array}{l}\text { Standard } \\
\text { Error }\end{array}$ \\
\hline Age & -0.001 & 0.000 & -0.003 & 0.000 \\
\hline Age-squared/100 & 0.002 & 0.000 & 0.004 & 0.001 \\
\hline Married & -0.093 & 0.002 & -0.162 & 0.002 \\
\hline Low Education & 0.075 & 0.002 & 0.107 & 0.002 \\
\hline Medium Education & 0.045 & 0.003 & 0.070 & 0.004 \\
\hline Non-white & 0.057 & 0.004 & 0.040 & 0.004 \\
\hline EU14 & 0.007 & 0.005 & 0.008 & 0.005 \\
\hline EUA8 & -0.016 & 0.007 & -0.001 & 0.008 \\
\hline Other Europe & 0.095 & 0.013 & 0.104 & 0.012 \\
\hline Asia & 0.034 & 0.005 & 0.012 & 0.005 \\
\hline Australasia & -0.036 & 0.007 & -0.042 & 0.006 \\
\hline Americas & -0.004 & 0.007 & -0.012 & 0.006 \\
\hline Africa & 0.017 & 0.005 & 0.034 & 0.006 \\
\hline No dependent children & -0.036 & 0.003 & -0.116 & 0.009 \\
\hline 1-2 dependent children & -0.039 & 0.002 & -0.046 & 0.002 \\
\hline North West & -0.018 & 0.002 & -0.006 & 0.003 \\
\hline Yorkshire \& Humberside & -0.017 & 0.003 & -0.014 & 0.003 \\
\hline East Midlands & -0.028 & 0.002 & -0.026 & 0.003 \\
\hline West Midlands & -0.022 & 0.002 & -0.017 & 0.003 \\
\hline Eastern & -0.035 & 0.002 & -0.028 & 0.002 \\
\hline London & -0.014 & 0.003 & 0.010 & 0.004 \\
\hline South East & -0.035 & 0.002 & -0.027 & 0.002 \\
\hline South West & -0.031 & 0.002 & -0.024 & 0.003 \\
\hline Wales & -0.014 & 0.003 & -0.006 & 0.003 \\
\hline Scotland & -0.014 & 0.003 & -0.005 & 0.003 \\
\hline Northern Ireland & -0.048 & 0.008 & -0.024 & 0.026 \\
\hline Interviewed in 2004 & -0.018 & 0.002 & -0.015 & 0.002 \\
\hline Interviewed in 2005 & -0.022 & 0.002 & -0.016 & 0.002 \\
\hline Interviewed in 2006 & -0.019 & 0.002 & -0.009 & 0.002 \\
\hline Interviewed in 2007 & -0.019 & 0.002 & -0.010 & 0.002 \\
\hline Interviewed in 2008 & -0.017 & 0.002 & -0.009 & 0.002 \\
\hline Pseudo R-squared & \multicolumn{2}{|c|}{0.101} & \multicolumn{2}{|c|}{0.191} \\
\hline $\mathrm{N}$ & \multicolumn{2}{|c|}{138827} & \multicolumn{2}{|c|}{151098} \\
\hline
\end{tabular}

Notes: Reference categories for education is high, for dependent children in household is 3 or more, for region is North East and for year of interview is 2009. Marginal effects have been calculated at sample means. Heteroscedasticity consistent standard errors reported. 